KEYWORDS

Urban poverty

History

Economic crises

Middle class

Social status

Social policy

Case studies

Metropolitan zones

Argentine

Gabriel Kessler

Associate Professor

Universidad Nacional de General

Sarmiento.

Researcher, Consejo Nacional de Investigaciones

Científicas y Técnicas (CONICET)

okessler@dd.com.ar

María Mercedes Di Virgilio

Associate Professor

Universidad de Buenos Aires.

Researcher, CONICET

- mdivirgilio@fibertel.com.ar
CEPAL REVIEW 95 A A GUST 2008

\section{The new urban poverty: global, regional and Argentine dynamics during the last two decades}

\author{
Gabriel Kessler and Maria Mercedes Di Virgilio
}

$\mathrm{T}$

his article analyses the various dimensions of the "new poverty" which emerged during the 1980s and 1990s. It begins with a review of the definitions of the term in Europe, the United States and several Latin American countries. The case of Argentina is then examined, paying close attention to the pauperization of the middle class in that country at several points between the mid-1970s and the crisis of 2001. Structural poverty - an older phenomenon - is used as a point of reference to describe the characteristics of the new impoverishment, the adaptation strategies evolved to address it using cultural and social capital, the erosion of collective social identity and the urban dimension of pauperization. The article concludes with an analysis of the transformations experienced by the new poor since the issue was first examined, as well as the specific challenges it poses for public policy. 


\section{I}

\section{Introduction}

The unique type of poverty that has emerged in Argentina following its severe impoverishment is one of the more unexpected consequences of the strong economic and sociocultural influence of the middle classes in that country. Between 1980 and 1990, workers lost approximately $40 \%$ of the value of their income. After a degree of recovery resulting from increased stability in 1991, they went on to lose another $20 \%$ between 1998 and 2001. Significant fluctuations continue to this day. ${ }^{1}$ The depth and persistence of the crisis which began in the mid-1970s drove the incomes of hundreds of thousands of middle-class and historically poor families below the "poverty line". In the Greater Buenos Aires area, currently inhabited by about 13 million people, poverty grew by $67 \%$ during the 1980s. One group stood out among the rest: the impoverished former members of the middle classes, now known as the new poor. To this must be added all those who, while not officially classified as poor, experienced a drastic decline in their income, forcing them to change their lifestyle completely. The new poverty has been a fixture in Argentine society ever since. During the 1980s, it was largely attributable to the impact of successive inflationary and hyperinflationary processes on income. During the 1990s, it was mainly a result of the high unemployment rates which set in early in the decade. Matters deteriorated as the new century approached. During the currency crisis of 2001 and 2002, poverty afflicted $40 \%$ of the population.

The pauperization of the middle classes marked a point of no return - the demise of a certain type of society. Argentina had hitherto been a relatively cohesive society (at least in comparison to most other Latin American countries). A strong middle class had

The authors gratefully acknowledge the contributions of the anonymous revisor of this article.

${ }^{1}$ The highest indices were recorded in late 1989 (38.2\%) and October $2002(42.3 \%)$. During the intervening years they always surpassed the two-digit mark. emerged, thanks to upwardly mobile tendencies ${ }^{2}$ which were assumed to be permanent.

The new poverty changed Argentine society's perception of itself. In the field of poverty studies, it prompted a reassessment of a sector previously thought to be relatively homogeneous. It also created new social policy challenges, as a group had now emerged whose needs, geographic location and cultural parameters differed from those of the traditional poor, and for which no specific programmes existed.

The case of Argentina may be instructive when analysing other societies in the region. The concentration of income in Latin America during the 1990s was, to a large extent, achieved at the expense of middleincome strata. (Hoffman and Centeno, 2003). While it is true that the characteristics of impoverishment depend on internal factors, the region's middle classes are nonetheless being pauperized. The subject has remained largely unaddressed in academic publications and public policy agendas. The situation is different in the countries of the centre, where, in ways that differ both from each other and from the Argentine experience, the concept of pauperization has been in use since the 1980s.

Today, two decades after the term was first coined, this article seeks to examine the research on the subject and describe the various dimensions of impoverishment. Priority is given to studies on the new poverty in different regions - particularly Western and Eastern Europe and the United States. Research on the subject in Latin America is then examined. The article concludes with a study of Argentina, paying special attention to the beginnings of pauperization in previous decades and the changes that have taken place since then.

\footnotetext{
${ }^{2}$ The idea of social mobility was reflected by actual events. According to a classic study on intergenerational mobility, based on data from 1960 (Germani, 1963), 36.5\% of Greater Buenos Aires survey respondents whose parents were blue-collar workers managed to obtain middle- and upper-class jobs within the span of one generation. Seventy-seven percent of those whose parents belonged to the lowest occupational category —unskilled workers - achieved either skilledworker status or middle class jobs within the same period.
} 
II

\section{The new poverty}

\section{from an international perspective}

The terms "new poverty" and "the new poor" are open to a variety of sociological interpretations. They are rooted in the same issue, framed from different perspectives: the characteristics of the new poor, which differ from the traditional features of poverty in each country. In Western Europe, the terms appeared in the late 1980s, as interest in the "new social question" was beginning to dawn. ${ }^{3}$ The turning point was an unusual increase in unemployment and poverty. Joblessness in what was then known as the European Community rose from $2.4 \%$ in 1973 to $11 \%$ in 1989 , leading to a "destabilization of the stable" (Castel, 1995) which affected groups previously thought to have been safely integrated into society. Joblessness rose, and its average duration increased, swelling the ranks of the long-term unemployed. Poverty also rose, bringing to an end the post-war period known as "the glorious thirty years". According to O'Higgins and Jenkins (1989), who studied relative poverty in 12 European countries, the number of poor persons increased from 3.6 million to 39.5 million between 1975 and 1980, and continued to grow, reaching 43.9 million in 1985 .

The number of persons relying on social services and other forms of assistance immediately rose. In the countries of the European Community, the number of welfare recipients doubled during the 1970s and 1980s. Traditional social measures were ill-suited to these new circumstances. The new poverty prompted a reassessment of the twin pillars of the post-war Western European welfare state: unemployment benefits - which were designed to address frictional unemployment, and were inadequate for individuals

\footnotetext{
3 The terms first appeared in a German publication dating from 1984, entitled Die Neue Armut ("The New Poor" - Balsen, Nakielski and others, 1984). They had already been employed, however, in a 1979 paper on pauperization in Italy (Carbonaro, 1979). A 1988 report by the now defunct European Economic Community used the concept of new poverty as part of its analysis of the social implications of a common market. The report noted that such a market could have a highly negative impact on certain areas and certain categories of the population, causing social exclusion, disadvantagement and ...the emergence of new forms of poverty (European Economic Community, 1988, p. 23 - emphasis ours).
}

who had been jobless for long periods of time and exhausted their welfare contributions - and benefits for persons deemed unable to work, which did not suit the characteristics of the new poor. A qualitative change had occurred in the population receiving assistance. The number of elderly persons and large families had declined, even as the number of working-age persons, single-parent households and unmarried individuals increased. This shift was reflected in the needs of the population. Excessive borrowing, rent delinquency, indebtedness and unpaid utility bills increased, as impoverishment altered people's spending habits and long-term financial commitments. Impoverishment also produced other phenomena, such as new types of informal economic activity, homelessness and higher crime rates.

Given these circumstances, the new poverty became a focus of media, academic and political attention in several countries. ${ }^{4}$ The middle classes became gravely concerned for their own sake: poverty was no longer "someone else's problem" - an issue facing what had previously been thought of as a "fourth world". The impoverishment of people with whom they shared the same social background, professional skills and sociocultural characteristics made the members of the middle class suddenly aware of their own vulnerability. The displacement of individuals previously thought to be safely integrated cast doubt on two core assumptions. One was a belief in the meritocratic nature of society - the idea that rewards and punishments are distributed based on personal merit. The other was the idea of social progress - a belief in the existence of mechanisms to direct the path of a developed society, to overcome its turbulences and guide it toward increasingly interconnected forms of equilibrium (Castel, 1995, p. 387).

These ideas did not go unchallenged in the academic sphere. Some argued that the concept of new poverty distracted attention from the plight of

${ }^{4}$ See Barthe (1987), Marklund (1990), Mingione and Zajczyk (1992), Neef (1992), Paugam (1991 and 1993) and Room (1989). 
the traditional poor, whose situation had become worse in relative terms. It was also argued that the term "new" conveyed the erroneous impression that poverty was a recent phenomenon (Kelly, 1984). Some social scientists preferred other emerging concepts, such as "social exclusion" and, in the case of France, "disaffiliation". In Great Britain, Gaffikin and Morrisey (1992) argued that "new inequality" was a more accurate description of the widening income gap between different social strata.

Indeed, in recent years, European interest in the concept of new poverty has declined. Social exclusion has become the concept of choice in intellectual and, above all, political circles. With the advent of the new millennium, downward mobility is no longer a novel concept. Much of the current research simply assumes that future generations will have a lower standard of living than their predecessors. Thus, for example, McDowell (2002) wonders how masculinity will be defined in a society where men will have difficulties fulfilling the role of provider for which they have been socialized, and authors such as De Regt and Weenik (2000) in The Netherlands study the educational strategies adopted by Dutch parents to protect their children from downward mobility. A minority group of experts in Western Europe associates new poverty with emerging immigration trends. The existence of a link between new poverty and the most recent population flows from Africa, Asia and Latin America would add a new dimension to the issue, given the territorial, economic, religious and ethnic tensions that accompany the insertion of "new populations" into European societies (Molina, 2001; Søholt, 2001; Bolt and van Kempen, 2003). These new arrivals thus face an accumulation of disadvantages, as their precarious living and working conditions are often accompanied by discrimination, loneliness, isolation and deracination.

In Eastern Europe, the abrupt collapse of socialist regimes generated strong interest in the concept of new poverty during the early 1990s, given the sudden pauperization that resulted from political and economic changes during the period. One of the main causes of impoverishment in this case was an increase in unemployment brought about by the shedding of surplus labour in every sector of the economy. Wages soon proved inadequate to cover the costs of a market economy, and the mercantilization of goods and services previously provided free or at low cost by the State had a crushing impact on already strained household finances. Impoverishment during those early years appears to have been dramatic, even in countries that established unemployment benefits relatively early on, such as Hungary, the Czech Republic and Poland (Tortosa, 1992). A more recent group of studies focuses on countries where the situation has been stabilized. Some of these studies compare the market transitions of former socialist states, as well as the medium-term impact of these processes on inequality and downward mobility (Titma and Murakas, 2004). Others reflect growing concerns regarding the impoverishment of ethnic minorities, particularly the gypsy or Rom people of Bulgaria, Hungary and Romania (Ladanyi and Szelenyi, 2002). References are made to a "new ethnic underclass" (Mitev, 2001) which suffers discrimination and has difficulty inserting itself into society due to its low human capital and migrant lifestyle. Also of interest are studies on the fate of former political elites, which became victims of downward mobility without slipping into actual poverty. Kryshtanovkaia (2005) has documented the exclusion of elites in Russia, describing the various ways in which they attempted - sometimes successfully, sometimes not- to transform their old political capital into economic capital. Asia is no stranger to interest in the middle class; studies such as the East Asia Middle Class Project and the Southeast Asia Middle Class Project have analysed middle-class tendencies in several countries, although upward rather than downward mobility tends to be the norm in this case (So, 2004). The emergence of a "new poor" population in Uzbekistan is also of interest. The political aspirations of this group are represented by a new populist left, which combines elements of the country's Soviet past with Islamist principles (Ilkhamov, 2001).

In the United States, the concept of new poverty has been used to analyse three issues of concern to sociologists in that country. One group of studies focuses on the "declining middle class", and reflects a traditional interest in social mobility, although in reverse order, since most studies focus on upward rather than downward mobility. The corporate restructuring process which began in the 1980s as part of the "new economy" reduced the number of mid-level jobs, displacing their occupants and causing a level of impoverishment not seen since the 1920s. ${ }^{5}$ This process also put an end to the expansion of the African American middle class, which first began in the 1960s. The downward mobility of this class had an impact on African Americans as a whole (Attewell, Lavin and others, 2004).

\footnotetext{
${ }^{5}$ See Blackburn and Bloom (1985), McMahon and Tschetter (1986), Newman (1989 and 1993), Rosenthal (1985) and Strobel (1993).
} 
A second group of studies on the "new urban poverty" focuses not on the middle class, but on the working classes which were displaced by an industrial restructuring process in the central and eastern cities of the United States. These studies explore the fate of less skilled, more socially and spatially segregated sectors -African Americans and, more recently, Latinosthus revisiting the "underclass" debate of the 1960s. The causes of the continued existence of this underclass have been a fundamental point of disagreement between progressive academics with more structuralist positions, such as Devine and Wright (1993) and Wilson (1987), and neoconservative intellectuals such as Auletta (1982), Mead (1986) and Murray (1984). The neoconservatives attributed its existence to the "perverse effects" of welfare programmes, which discouraged work and personal responsibility. During the Reagan administration, they successfully argued for the reduction of such programmes.

A third group of studies lies at the intersection between immigration and social mobility research. These studies focus on the impoverishment of the "new second generation", particularly the children of Latin American immigrants. This downward mobility casts doubt on classical assimilation theory, which holds that the entrepreneurial spirit of second generations, combined with their greater human capital, propels them upward. Portes and Zhou (1993) argue that a "segmented assimilation" process exists, whereby structural and human-capital factors in the receiving country hinder successful insertion, transforming second generations into a "new rainbow underclass" organized along strongly racial lines. This hypothesis has been supported by some of the research, including the work of Kazemipur and Halli (2001) in Canada, but other experts have called it into question. After studying a cohort of children of Mexican immigrants, Waldinger and Feliciano (2004) concluded that they were not an underclass, but rather a generation characterized by short-range upward mobility, living in the lower reaches of the working class. Sabogal (2005) studied the particular case of Peruvian professionals who migrate to the United States and become victims of downward mobility, as they lose their legal immigration status or fail to validate their professional credentials. Finally, Fothergill (2003) has examined the consequences of a seldom-studied phenomenon: downward mobility resulting from natural disasters.

Thus, in the context of the new developments of the 1980s, the concept of new poverty focuses on the emergence of groups characterized by strong downward mobility, as well as previously unknown types of poverty. This casts doubt on the idea that such groups are homogeneous, and highlights the need for public policies specifically designed for a population whose needs are qualitatively different from those of the traditional poor.

\section{III}

\section{The new poverty in Latin America}

The persistence of traditional poverty and the fact that the middle classes have historically been viewed as a small part of the population may explain why the concept of new poverty does not carry as much weight in Latin America as it does elsewhere. The term is largely absent from the innumerable poverty studies published by international organizations. Nevertheless, the vulnerability of the middle classes has been a subject of debate in Latin American countries, albeit a minor one. Latin America's middle classes were affected in a variety of ways by the debt crisis of the 1980s and the phenomena that ensued, including structural adjustment programmes, concentration of income, rising prices for private services and the deterioration of services offered by the State, as well as the changes that occurred in the labour market during the 1990s.

In one of the first papers of its kind to be published in Chile, Lomnitz and Melnick (1991) examined the situation of teachers under the Pinochet regime. Educational reforms and the proscription of trade unions had deprived them of economic and social power and, most importantly, weakened the foundations of compadrazgo - a system for the informal exchange of favours among the members of the middle class, most of whom were government bureaucrats. This broad reciprocal network afforded its members access to the best health benefits, education and government jobs. Concern over pauperization resurfaced almost two 
decades later, from a different perspective. According to Ugalde and Prieto (2001), after the notion of an "emerging middle class" — characterized by upward mobility toward skilled positions in an expanding services sector - first appeared, the limitations of the development model and the end of the decline in poverty drew renewed attention to pauperization. By the year 2000, the country's poorest sectors were bearing the brunt of job loss and income depreciation. The rise of open unemployment in the country and its metropolitan region in 1998 and thereafter led to "the reproduction of high inequality rates" (Sabatini and Wormald, 2005, p. 233). The impoverishment of lowermiddle-income strata, coupled with the appearance of an upwardly mobile emerging middle class, are two aspects of inequality in Chile identified by Torche (2005). According to this author, the Chilean social structure is characterized by strong upward mobility, concentration of income in the upper deciles and a negligible difference between lower- and lower-middleincome strata, which makes the latter highly vulnerable from a structural standpoint. Any increase in the precarity of their labour conditions, or any downward occupational shift, however slight, may precipitate a slide into poverty.

Moreover, in a labour market which places a premium on highly skilled workers, a new "hard poverty" has emerged among individuals and households that lack the minimum resources and opportunities needed to overcome poverty through their own efforts. The situation is made worse by a mixed welfare model and the mercantilization of social services on the basis of household socio-economic status (Wormald, Cereceda and Ugalde, 2002). This is a critical factor when services such as education are involved (Sabatini and Wormald, 2005). As noted by Torche and Wormald (2004, p. 70), investment in education by Chilean families does not offer the same returns across the social spectrum. It is less profitable for lower-middleincome strata, since the labour market encourages the reproduction of a relatively polarized wage structure. Among middle-income strata, no difference is observed. Espinoza (2006) completes the picture with an analysis of data from an occupational mobility survey. ${ }^{6} \mathrm{He}$ notes that, while positions requiring more skills have been available to inhabitants of the capital

\footnotetext{
${ }^{6}$ Espinoza (2006) used data obtained from a survey conducted in Montevideo, Buenos Aires and Santiago in September of 2000, as part of Fondecyt Project 1990818. The survey traced the job histories of male and female workers between the ages of 35 and 50 .
}

- Santiaguinos - for the last few decades, exclusion still has a major impact on the lower-middle classes. In a country such as Chile, characterized by shortrange occupational mobility, positions requiring skilled workers remain inaccessible to individuals from modest middle class families. In Chile, the new poverty has also been associated with place of residence. Tironi (2003) has argued that housing creates new forms of precarity, due to the changes in social capital that result from the destruction of community ties in an individual's place of origin.

Poverty in Mexico has distinguishing features of its own. Low unemployment during the 1990s did nothing to prevent a sharp reduction in wages and the growth of the informal sector (Bayón, 2006). Low open unemployment was accompanied by high informalsector employment, low wages and a low ratio of wages to GDP (López, 1999). The data available on Mexico City also suggest that income is becoming polarized. Among the working population in general, only managerial staff and semi-professional service workers experienced any real improvement in their incomes during the 1990s; toward the end of the decade, they were earning 25\% more than they had been in 1990 . Other occupational categories -including middle strata such as clerical workers, own-account workers, skilled, semi-skilled and unskilled manual labourers and manual labourers in low-skill services - saw their real income decline, falling to pre-1990 levels by the end of the decade.

In their analysis of intergenerational social mobility in urban areas of Mexico, Cortés and Escobar Latapí (2005) observed a decline in mobility for all social strata during the economic restructuring period (1988-1994). This decline had a much stronger impact on lower-income strata: unskilled factory workers, informal service workers, ejidatarios (farmers working community land), small rural landholders and day labourers. Under the new economic model, inequality of opportunities between lower- and upper- class individuals - the latter being defined as professionals and employers of more than five workers-increased. As inequality grew, the occupational mobility structure also became more rigid. Fewer opportunities are now available to younger generations. Parrado (2005) has shown that, for new workers, an advanced education offers no protection from downward mobility -a finding which casts doubt on the cherished belief that education is a path toward mobility.

In addition to Argentina, which is analysed in Section IV, two other Latin American countries have 
attracted attention as a result of the impoverishment of their middle classes: Uruguay and Costa Rica. Inequality in Uruguay has traditionally been far lower than that of most countries in the region, as well as the regional average. By the late 1980s, however, new poverty among former members of the middle classes was becoming a concern (Kaztman, 1989). Recent studies have sought to determine the causes and consequences of increased inequality. Impoverishment has been linked to the behaviour of the labour market, particularly an increase in open unemployment rates and informal employment, as well as a relative decline in government employment, which had helped bridge wage differences (Kaztman, Filgueira y otros, 2005). Among wage-dependent workers, income differences between heads of household with different levels of educational attainment increased, and individuals from households with at least one unemployed member began to fall further behind (Bucheli and Furtado, 2004). Impoverishment was thus driven by the descent into poverty of the lower-middle classes: a "short fall" similar to that experienced by the more vulnerable members of the Argentine middle class.

The case of Costa Rica bears certain similarities to that of Argentina. It is no coincidence that in Costa Rica, a country whose social identity in the region is based on having a strong middle class, every crisis raises concerns about the possible disappearance of that class. These concerns seem to reflect larger questions regarding changes in the overall social structure of the country. Vega Martínez (1999) has shown that, while the middle class remains stable from a quantitative perspective, its standard of living has declined. The impact of falling government employment, as well as the increase in average household spending on private health and education services due to the declining quality of State services, suggests that the middle class is strongly tied to the State. Thus, Martínez concludes, the crisis of the Costa Rican middle class began with the crisis of the State. Like its Uruguayan counterpart, the Costa Rican middle class has been affected by the destabilization of the mechanism that made equality possible (Montero and Barahona, 2003). There are also signs of impoverishment in the Bolivarian Republic of Venezuela, which has experienced a significant increase in unemployment and poverty, and Cuba, where, according to Hoffman and Centeno (2003), the influx of foreign capital and the privatization of certain sectors of the economy have created a "dollar apartheid".

The fate of the middle class has also been an issue in Brazil, although the question is not framed in terms of the new poverty, but rather from the perspective of a middle class facing multiple threats. The first is a lack of safety in urban areas. Caldeira (1996) describes a middle class that surrounds itself with fortified walls in private enclaves. Others speak of more traditional segments of the middle class that find themselves threatened by changes in the economy and the working world. O'Dougherty (1999) describes a middle class fearful of being forced to change its consumption habits; unlike its Argentine counterpart, which blames its troubles on the neoliberal economic model, the Brazilian middle class believes neoliberal governmental reforms and economic policies will restore its consumption patterns, which are believed to be in jeopardy. Authors such as Valladares, Pétreceille and others (2005) question the idea of "two Brazils", one marginalized, the other formal and modern. Instead, they speak of a "complex Brazil" that owes much of its nature to the growing importance of its urban middle classes. Over the last few decades, the so-called "democratization of consumption" of durable goods among low-income Brazilian families has increased this complexity. Citing household consumption survey data, Mota Guedes and Vierra Oliveira (2006, p. 1 ff.) describe the manner in which "low-income Brazilians began to purchase goods and services traditionally reserved for the middle and upper classes", such as duplex refrigerators, mobile phones, automobiles, plane tickets, package deals for tourist travel and credit cards. Access to these goods was facilitated by inflation control, increased credit and the falling prices of goods and technologies. In this regard, one might ask whether the democratization of consumption is a sign that the borders between social classes are being redrawn, or whether new class distinctions are being created based on the locales where consumption takes place, the quality of the goods consumed and access to services. Guedes and Oliveira also question the sustainability of the debts acquired by low-income families, as well as the adequacy of their investment in education. 


\section{IV}

\section{Impoverishment in Argentina}

\section{The causes of impoverishment}

In Argentina, the impoverishment of the middle classes is a result of factors which have accumulated over the last two decades. Any summary of the experience of the new poor in that country would have to mention, first and foremost, the depreciation of income among its intermediate socio-professional categories after the military coup of 1976. Indeed, in Argentina, unlike in Western Europe, the new poverty was initially caused by falling wages rather than joblessness. The second phase of impoverishment began in the 1990s, as unemployment increased. It gained momentum in 1995, as the country's income distribution became skewed against less-skilled workers - a phenomenon which also affected the lower-middle classes. Growing job insecurity also became a factor, affecting less-skilled workers first and then spreading to skilled ones.

These factors bear closer examination. The impoverishment of the 1980 s was caused by wage depreciation, as well as the loss of direct and indirect job benefits, although inflation and low productivity kept unemployment relatively low. The hyperinflation of 1989 marked a turning point, after which impoverishment accelerated as unemployment rose. In the Greater Buenos Aires area (the country's most populous district), for instance, unemployment rose from $6 \%$ to $17.9 \%$ between 1991 and 2000 . The approval of the Ley de Convertibilidad ("Convertibility Act", also known as the Cavallo Plan) in 1991 encouraged macroeconomic stability and growth, but failed to reduce growing income inequality between households or solve the problems afflicting the labour market (Altimir and Beccaria, 1999). The temporary improvement achieved during the early 1990s partially reversed the deterioration of wages, but did not restore them to 1980s-era levels. Incomes deteriorated further in 1994 and succeeding years, when inequality was exacerbated by a decline in the wages of less-skilled workers: by May of 1999, individuals in the richest decile of the population were earning 25 times more than those in the poorest decile, compared to 23 times two years earlier, 15 times in the early 1990s and eight times in the early 1980s (CELS, 2001).
The crisis of the labour market and the growth of household income inequality had a significant impact on the living conditions of certain sectors of the middle class. Over time, they gave rise to a new poverty linked to a lack of monetary resources. In 1980 , poverty caused by income inadequacy stood at 3.2\% (Minujin, 1992); by the end of the 1990 s, $26.7 \%$ of the population $-18.9 \%$ of households - was earning less than the amount required to cover a basic basket of goods and services (INDEC, 2003). Save for the temporary improvement experienced by certain groups in the early 1990s as a result of economic stabilization, income poverty became an established structural trend.

As of late 2001, the Argentine labour market was characterized by high open unemployment and increasingly precarious and unstable jobs. Job insecurity was a result of the growing importance of unregistered wage labour (informal employment) and the less structured nature of self-employment. As Beccaria and Mauricio (2005) have explained, these were mutually reinforcing phenomena. On the one hand, the lack of full, stable employment forced many individuals to accept low-quality jobs, thus increasing job precarity; on the other, the rising number of precarious jobs increased the rate at which people became unemployed, usually for short periods of time. A large segment of the labour force moved regularly from one precarious job to another, with neither employment nor unemployment lasting very long.

Toward the end of 2002, labour market conditions began to improve, and poverty began to decline as a result. Economic growth was accompanied by a rapid increase in employment and a steady drop in the joblessness rate. Wages, on the other hand, were slow to recover. Even today, average wages are lower in real terms than they were in 2001. Questions arise as to the impact of these developments on different groups of workers. Has the gap between the two extremes of the wage pyramid decreased? A comparison of workers at opposite ends of the spectrum shows that the average wages of the top $10 \%$ are 30 times higher than those of the bottom $10 \%$. Economic activity has grown by 9\% over the last few years, and the number of jobs has increased by approximately two and a half million. Real wages, however, have failed to keep pace with the 
country's economic recovery and increased employment rate, ${ }^{7}$ remaining at pre-2001 levels. Meanwhile, the wage gap between opposite ends of the spectrum has been growing since 2004. Wage inequality, which has been on the rise since the mid-1970s, has decreased, but only to a limited extent. There can be no question that inequality itself is not only high, but has not changed significantly compared to the high levels of the late 1990s. How has all of this affected the new poor? Those who were unemployed but possessed social capital and youth may have been able to re-enter the labour market. Similarly, those who were employed in low-paying jobs may have experienced a measure of improvement in their incomes.

\section{The experience of pauperization}

Impoverishment without job loss is a distinct phenomenon which differs from unemployment or structural poverty. Its main characteristics should therefore be examined. Research on pauperization by the authors of this article (Kessler, 1998 and 2000; Kessler and Di Virgilio, 2005; Minujin and Kessler, $1995)^{8}$ and others (Minujin, 1992; Feijoó, 2001) has gradually shed light on the process that characterized early poverty in Argentina. One of the first features of the new poor that should be noted is their hybrid status; they live in close proximity to the middle classes, and are linked to them by common economic and cultural variables with long-term effects, such as education and family composition. Their families are less numerous than those of the structural poor, but they resemble those families in that their incomes are low, they suffer from underemployment and they lack social coverage. These are all short-term variables resulting from the crisis. The data also suggest that the new poverty is characterized by polarization

\footnotetext{
${ }^{7}$ The impact of inflation, which has been a fact of life in Argentina since the end of convertibility, is also reflected by wages, which have lost purchasing power. For instance, in April 2005 the consumer price index (Ipc) increased by 4\%, while the prices comprising the indices that measure indigence and poverty - the basic food basket (Cba) and the total basic basket (Cbt) - increased by $5.8 \%$ and $4.4 \%$, respectively. Consequently, households need more resources to overcome the indigence and poverty thresholds set by those baskets.

${ }^{8}$ Unless otherwise noted, the following three sections are based primarily on these works, which include quantitative and qualitative research conducted in Buenos Aires, Santa Fe, Tucumán and Presidencia Roque Sáenz Peña during the 1990s. More specific studies were later conducted in Buenos Aires (Cortés and Kessler, 2004; Kessler, 2008).
}

and heterogeneity. Statistics show marked income reductions in all occupational categories during the 1980 s, accompanied by an increase in the gap between those earning the highest wages and those at the bottom of the scale. The new poor that emerged as a result of this process were a heterogeneous universe made up of the "losers" of each occupational category. This quantitative diversity had a qualitative counterpart: the diverse socio-professional profiles of the new poor were accompanied by diverse social backgrounds. Individuals differed in terms of socialization, family origin, education and professional history. Before encountering poverty, each member of the group had evolved different expectations, beliefs, consumption patterns and potential resources. Once pauperization occurred, they each experienced poverty differently.

Pauperization is a general distortion that affects every aspect of household finances, forcing families to review, modify and forego even routine, seemingly unproblematic practices (Feijoó, 1992). It may entail removing a child from the private school his or her siblings attended, changing the family diet, restricting use of the family car, cutting back on trips, staying home from parties for lack of appropriate attire, cancelling club memberships, giving up computer use, therapy, football, music, magazines, movies, holidays, prepaid medical care and certain social activities, falling dangerously behind on taxes, discontinuing insurance payments, reneging on half-paid loans, restricting dining invitations, cutting back on dental care and reducing electricity and telephone consumption, among other measures.

This phenomenon, which may be described as a constant coercion toward change, is one of the unique features of impoverishment. It differs from stability in that, in a stable environment, routines tend to become established, and the passage of time does not entail a constant stream of coerced decisions. It also differs from upward mobility, which is characterized by voluntary change. Downward mobility makes life increasingly complex for those trying to manage it; the need to do so is made all the more urgent by the fact that impoverishment affects not only the private sphere, but also the surrounding environment. Interconnected layers of experience -ideas, beliefs, expectations and perceptions previously taken for granted- crumble under the weight of its impact on daily life. Pauperization alters the lives of individuals and throws their surrounding environment into disarray. This duality of perception makes "adaptation" in a traditional sense - the ability to adjust to a defined or definable new situation - impossible. Individuals 
are forced to make sense of a situation for which no explanation can be found either in the "common stock of societal experience" or their own family histories.

This is what makes pauperization a unique phenomenon in modern Argentine history. The impoverishment of a significant portion of the middle class was an abrupt departure from the country's traditional generational and historical/cultural model. Not family socialization, nor the surrounding culture, nor any common coping technique could have prepared these individuals for the final, irreversible poverty they faced. In this they differed from their counterparts in the United States, who still recalled the Great Depression, and were thus able to draw on those experiences (Elder, 1974). The downward slide of the new poor in Argentina marked the end of their sense of family trajectory, where every generation moved higher up the social ladder than the one before. Irreversible impoverishment marked the end of that journey, a turning point which threatened a continued decline, culminating in the dreaded downward mobility of their children. Among the subjects interviewed for this article, this departure from the country's historical/ cultural and generational model was met with general incomprehension, reflected by an inability to categorize the new environment. This explains the seemingly irrational behaviour of many families that tried to maintain their usual consumption patterns, and even became indebted to do so, convinced that what they were experiencing was simply one of the country's cyclical crises. The situation was not believed to be possible, and therefore no internalized strategies were available to address it.

\section{Adaptation strategies: uses of social and cultural capital}

The first thing that drew the observer's attention when visiting the homes of the new poor during the 1990s

\footnotetext{
9 See Schutz's concept of "stocks of knowledge". According to Schutz, "Any interpretation of the world is based on a reserve of past experiences, be they our own or those which have been passed down to us by our parents or teachers. These experiences, in the form of 'available knowledge', serve as frames of reference" (Schutz, 1987, p. 12). According to Cefaï (1994, p. 112), this reserve of experiences does not always provide the tools necessary to interpret a new situation. "The problem arises when an actor does not know what to say or do, cannot understand what is happening, cannot understand or reach agreement with others, fails to connect a topic to existing relevances... (...) He is faced with the inadequacy of his "prestructure of understanding"; his field of interpretive and motivational foresight is not such that he can define and control the situation."
}

was an apparent dislocation of the traditional hierarchy of needs (Kessler, 1998; Minujin and Kessler, 1995). In an effort to "hold on", some individuals who did not even have health insurance were still taking annual seaside vacations.

Others continued to send their children to private schools, even though they were unable to afford health care, clothes and recreational activities. Despite deplorable living conditions, some continued to pay for high-quality health care, and it was not unusual for deeply indebted individuals to frequent country clubs and regularly update their wardrobes. What had happened? Had households been shaken to such an extent that the traditional hierarchy of needs had been abandoned? No; the seemingly distorted priorities of the new poor were a function of the alternative resources they possessed, thanks to their accumulated cultural and, above all, social capital. Unlike money, these resources were indivisible, given their limited nature. Thus, belonging to a family of doctors or having a network of friends in the textile industry might provide specific, predetermined solutions to certain problems, but nothing else. In many cases, the types of capital employed by the new poor had been developed in previous social situations, for different purposes; in others, they had never been recognized as capital.

If this phenomenon is compared to the relationship between poverty and political patronage, the latter may be described as one of the traditional mechanisms for the informal distribution of goods and services to the poor. Patronage is made possible by discretionary control over social aid in heavily populated, electorally significant areas. Transactions of this type seem less feasible in the case of the new poor, who are not concentrated in specific geographic areas and are not the object of specific social policies. They must negotiate for themselves if they wish to obtain scarce goods or additional benefits, or simply reduce the inconvenience of dealing with government institutions. In this regard, cultural capital, in its "embodied State", ${ }^{10}$ offers a number of advantages when dealing with schools, hospitals or trade union savings associations. These advantages are clear when

\footnotetext{
${ }^{10}$ According to Bourdieu (1979), cultural capital exists in three states. This article focuses on the "embodied state" (long-lasting dispositions of the mind and body), which consists of attitudes, inclinations to perceive, feel, do and think, that are internalized by individuals based on their objective life conditions, and serve as unconscious principles of action, perception and reflection (Accardo y Corcuff, 1986, p. 229).
} 
one compares the treatment of the new poor to that of the structural poor in the same institution. By mobilizing cultural and social capital, the former gain better access to specialists, hospital accommodations and free medicines. They are better able to secure a place for their children at the more prestigious public schools, as well as the few existing full-day schools (coveted by families with two working parents) and nurseries for children under four, which are not part of the mandatory educational system, and are thus not required to serve the entire population. The conflicts observed by the authors of this article at municipal offices involved the distribution of benefits, aid and financial subsidies; those in the health care system arose when individuals attempted to obtain benefits not clearly established by institutional regulations.

Several of the new poor interviewed for this article claimed to have established relationships with State bureaucrats that afforded them a degree of preferential treatment. Nevertheless, most of their dealings with institutions were tense. Disputes usually began when they began to "speak up", since they were financially unable to "exit" the system and engage a private service (Hirschman, 1970). Clients would typically raise their voices to employees, strenuously reminding them of their obligations: how they should do their jobs (particularly in terms of customer service), how - and how fast - they should process information, and so forth. Complaints about staffers might expand to include the institution in general, with occasional references to "rights", as well as the "respect" and "consideration" they were due on account of their social rank, professional status or other attributes that distinguished and elevated them above the general mass of people in the system. It was not uncommon for users to threaten to lodge complaints and "report" employees, not through traditional channels (i.e., through a complaint log), but rather by speaking directly to higher-ups whom they claimed to know personally.

Despite their efforts, the new poor were beset by uncertainty regarding the effectiveness of their strategies. Every new interaction was a trial-anderror experience. No asset could be recognized as cultural capital until its effectiveness had been proven. Attributes shown to be effective in the past (academic degrees, professional prestige, vague references to rights or citizenship) might be transformed into capital if their value was successfully demonstrated, only to lose their effectiveness on the next attempt (at a different institution, at the same institution with a different employee or even at the same institution with the same employee). Users might even find themselves rebuked with a reminder that "everybody has the same rights".

Social capital was used by the new poor to access goods and services to which they were accustomed, but could no longer obtain through ordinary market exchanges. Accordingly, they sought out potential suppliers among their acquaintances, creating personal networks that fulfilled some of their needs. An analysis of these networks shows that they were not created to exchange goods outside the market - unlike the classical reciprocal relationships described in studies of marginalized groups in Latin America (Lomnitz, 1975) - but rather to stretch the normal rules of exchange, in order to obtain discounts, negotiate endless payment plans and even barter certain goods, usually with professionals in the services sector. As mentioned earlier, the assets that are transformed into cultural or social capital when facing impoverishment are actually attributes built up during previous social situations, for other purposes; they may not even have been recognized as assets. For example, for a professional seeking career advancement, having a large circle of colleagues might constitute a valuable form of social capital. However, if the professional becomes impoverished, and wishes to lessen the impact of falling consumption levels, this accrued capital (having colleagues) becomes less valuable. Access to a more diverse group of professionals would entail more potential services, and thus be of greater use in fulfilling unmet needs. Moreover, given the change experienced, the favours needed from others will be substantially different (loans rather than referrals, for example). There is no way of knowing whether someone who provided a given service in the past will be willing to accommodate the new requests.

Social and cultural capital theory presupposes a stable environment, in which social relationships are accumulated for a specific purpose: upward mobility or surviving poverty. Impoverishment entails a change of circumstances which casts doubt on the effectiveness of accumulated social capital; its reconversion is not assured. From a conceptual perspective, the new poverty highlights the uncertain nature of the resources available. The question of whether or not they can be employed and recognized as capital can only be settled by attempting to use them. The difficulty of creating stable new resources was greater for individuals who became impoverished during the crisis of 2001. The crash was so sudden, violent and widespread that, in 
most cases, there was no time to develop the adaptation strategies described above. Moreover, given the large number of people affected, it was impossible to develop the type of networks that would have emerged during a less abrupt and massive downslide (Cortés and Kessler 2004).

\section{The erosion of social identity}

How do the new poor describe their place in the social structure? Does pauperization affect previous social classifications? ${ }^{11}$ The new poor interviewed for this article asked themselves - and the sociologists interviewing them- who they were now. There is no single, socially classifiable answer to this question. Unlike unemployment, impoverishment without job loss involves no "detachment rite" such as dismissal, which is both the termination of an existing status and the beginning of a new one (for example, the transition from general manager to unemployed professional). It has been observed, however, that pauperization casts doubt on a crucial self-classification: membership in the middle class, which is closely linked to the Argentine social identity. During the hyperinflationary period of 1989 and 1990, the "end of the middle class" was a looming spectre which threatened to annihilate an entire social stratum, and the national ideal it embodied (Sigal and Kessler, 1997). Its disappearance would turn Argentina into Brazil; the country's three-part balancing act would be traded for a dichotomic face-off between the upper and lower classes. Hyperinflation was a highly destructive phenomenon which left almost no social group untouched, turning concerns about the middle class into a generalized fear that the class itself was disappearing. Pauperization, on the other hand, is a long-term process. It only becomes visible as a social problem after a certain amount of time has elapsed.

Thus, during the interviews conducted for this article, the issue was formulated from an individual perspective, in terms of membership in or expulsion from a given category. It was not reducible to a single question, but rather involved a chain of concepts surrounding the term "middle class". The initial

\footnotetext{
${ }^{11}$ These questions involve "social self-classification" - self-described membership in a given category, such as "middle class" or "poor". Self-classification is an imagined position within the social structure, held vis-à-vis other groups in the social world. For example, the existence of a middle class presupposes that of a lower and upper class. A change in an individual's self-classification may entail a change in the way he or she views the entire social structure.
}

interview question involved class membership, and forced respondents to define their imagined criteria for inclusion. Did they belong to the middle class by virtue of past status, scholastic achievement or cultural baggage? The second question involved the scope of the change: was it an individual matter, or did it extend to an entire social group, or to society as a whole? Furthermore, if an individual was no longer in the middle class, what was his or her new status?

Underlying these questions was the suppression of certain consumption habits. Self-inclusion in the middle class was based on real or potential access to goods and services beyond those required for mere survival: certain types of clothing, outings, vacations, appliances, vehicles, and so forth. Education may have been important, but consumption was the decisive factor. This was so because an individual could belong to the middle class without having an academic degree, and, given the crisis, even those with advanced educations might find their class membership questioned. Impoverishment showed that self-perceived membership in the middle class was based on daily consumption patterns. This explains the prevalence of self-inclusion under normal circumstances, as well as its extreme fragility during times of impoverishment. It involves no initiation rite, but its very ease becomes an Achilles heel during crises, since no diploma or institutional position is fully effective as a retention mechanism.

Be that as it may, the subjects interviewed for this article fell into two categories: those who simply continued to claim membership in the middle class, and those who believed themselves to have been expelled. The former listed assets that supposedly compensated for their diminished standard of living — degrees, job status, cultural baggage, habits, past life. Some spoke of a "massive devaluation of the middle class", which had seen its collective standard of living decline. Nevertheless, they did not question their own class membership, nor the existence of the middle class as a distinct social stratum. They simply stated that it had become an "upper-lower class". In their view, what had occurred was more a collective change than an individual expulsion; the country's tripartite social structure remained intact, with a third segment occupying the space between the upper and lower classes. The relative position of the middle class had simply declined, bringing it closer to the lower class. Have defined the middle class in relative, hierarchical terms, they believed class membership was a matter of staying within its imagined boundaries. This explains 
why many interviewees refused to entertain the idea that they might be legitimately entitled to benefits such as free food. Even families living in abject poverty believed such benefits were "not for them", but rather for the "real poor". Accepting social aid would stigmatize them; by rejecting it, they were trying to avoid being labelled.

For those who believed they had been expelled, on the other hand, "lifestyle" was the key component of class membership. Self-exclusion was more common among those who possessed no degrees or skilled positions to compensate for their deteriorating standard of living when asked to define their social identity. From positions of relative proximity, individuals adopted different positions, depending on whether they emphasized what had been lost or what remained ("I am still a professional, no matter what"). Following their (self-) declared expulsion from the middle class, they needed a new category with which to identify. Not surprisingly, they refused to define themselves as "poor". The poor were a structural group, from which they were separated by both their past and their current lifestyle. The hybrid nature of the new poverty allowed for a variety of different responses to questions involving social identity. Sometimes, unable to decide between the middle class and the "poor class", they defined themselves as "working class", thereby switching the parameters of classification from lifestyle to source of income (wage labour). Interviewees tended to be hesitant rather than decisive in their responses, however; social identity appeared to be a matter of some doubt.

This situation was characteristic of the new poverty during the mid-1990s. Research conducted in mid-2002 showed a number of interesting changes. First of all, those who believed themselves to have been expelled from the middle class were now in the majority, and many of them described themselves as members of the new poor (González Bombal, 2002). The term had spread beyond academia to those it was intended to describe, and they appropriated it to such an extent that, in a 2005 study on perceived social identity, $33 \%$ of respondents described themselves as members of the "impoverished middle class" (Grupo ccR, 2005). ${ }^{12}$

\footnotetext{
12 Twelve percent of respondents described themselves as lower class, while $55 \%$ described themselves as middle class. This shows that the middle class is still viewed as a privileged social category. According to official statistics, poverty at the time of the survey stood at $43 \%$.
}

This change of social identity was accompanied by an easing of efforts on the part of the new poor to distance themselves from the "real poor". This was reflected mainly by a change of attitude regarding the welfare benefits they had previously refused. Hence, some of them - a small group, given the eligibility requirements involved - enrolled in the Unemployed Heads of Household Plan, a massive income-transfer programme enacted following the 2001 crisis. ${ }^{13}$

What is the social identity of the middle class today? Has it reconstituted itself among the impoverished as the economy stabilizes? Recent research details the socio-cultural transformations that have occurred within the upwardly mobile sectors of the Argentine middle class since the 1990s. These changes include greater individualism, marked consumerism, avoidance of the lower classes and limited social interaction with other strata. This is most clearly exemplified by the country's new gated communities and developments (Svampa, 2004; del Cueto, 2007). In terms of consumption, goods which were once limited to the middle and upper classes have spread farther down the social ladder, thanks to falling prices and easier access to credit. ${ }^{14}$ This resembles a similar process which took place in Brazil, as explained above. In fact, in 2006, marketing companies abandoned access to durable consumer goods as a class indicator, choosing other variables instead, such as participation in expensive health care programmes or the hiring of employees. Ownership of telephones, mobile phones and traditional household appliances (refrigerators, stoves and washing machines) is widespread, and can hardly be said to constitute a boundary between classes. Other goods, such as computers, Internet access and vehicles, are unequally distributed between stable and impoverished sectors of the middle class (Grupo ccR, 2005). The new strata will soon have access to these goods, however, given their gradually declining prices. The question that remains is whether these impoverished sectors, which have now been partially stabilized, are recovering old ways of defining their identity, through renewed access to consumption, or whether status indicators are changing,

\footnotetext{
${ }^{13}$ According to a 2007 study, $24 \%$ of Jewish welfare recipients - most of them members of the new poor- were enrolled in the Unemployed Heads of Household Plan or similar programmes established by the City of Buenos Aires (Kessler, 2008).

${ }^{14}$ Despite the wider distribution of goods throughout the social structure, research by Mora and Araujo (2007) before the crisis showed that the main gaps were to be found between the uppermiddle and lower-middle classes, and between the lower-middle and lower class.
} 
with class identity now depending on new consumption patterns and social practices rather than traditional durable consumer goods. In other words, it remains to be seen whether widespread ownership of goods that once conferred status will help to rebuild the social identity of impoverished persons, or whether their recent self-classification as members of the new poor will be altered by access to consumer goods similar to those which, in the past, would have reaffirmed class membership.

\section{The urban dimension of new poverty}

One seldom-explored aspect of the new poverty is the spatial distribution of the situations and manifestations to which it gives rise, as well as its impact on access to housing and urban services. The new poverty represents a break with the decades-old logic of poverty in Argentina: villa (shantytown) = poverty. The presence of villas miseria (shantytowns or slums) in the city are a territorial manifestation of the position occupied by the poor in the social structure. The new poverty contradicts this logic, which is characteristic of structural poverty. Social status today does not necessarily entail uniform ways of occupying territory or accessing housing and urban services. The new poverty is more diffuse and concealed than structural poverty; it changes the customs and practices of a city, in the city, giving rise to new conflicts in urban life (Prevot Schapira, 2002).

According to SIEMPRO (2001), 91\% of income-poor households in the Buenos Aires Metropolitan Area are in urban neighborhoods. Only 9\% are located in shantytowns or squatter settlements. Nevertheless, an analysis of the composition of urban neighborhoods shows that $26.8 \%$ of their households are income-poor. ${ }^{15}$

This suggests that the territorial logic underlying structural poverty is different from that which informs the new poverty, even though the two cannot be viewed as entirely separate "worlds".

Several decades of impoverishment, coupled with the impact of unemployment, have broken the mould that once confined the poor to clearly defined and identifiable geographic areas. Poverty during the 1990s arose in the nooks and crannies of cities, and manifested itself in the progressive deterioration and transformation of living spaces; a process which

${ }^{15}$ In shantytowns, this figure is $59.1 \%$. included gradual changes in the use and condition of physical structures. ${ }^{16}$ The houses of the new poor remained in middle-class neighborhoods; if they were lucky, the new poor retained ownership of their dwellings, but they were unable to make improvements or invest in maintenance. Some were even forced to modify their homes to make room for workshops or small stores.

The deterioration and changing uses of physical structures were accompanied by a change in the logic underlying middle class access to the city. The middle classes had traditionally gained access to the city in general, and their habitat in particular, through the market; that was the social mechanism through which they obtained housing and urban services. Pauperization seriously compromised their ability to employ market mechanisms, particularly since their impoverishment was linked to unemployment. As Badcock has pointed out (1984, p. 171), a country's employment structure - and the position families occupy within it - strongly affects access to housing. In an environment in which unemployment had reached vast sectors of the population (climbing as high as $21.5 \%$ ), traditional mechanisms for the acquisition of housing and urban services ceased to function. ${ }^{17}$

The crisis of traditional social mechanisms for acquiring housing is reflected by phenomena such as squatting. Over the last two decades, the poor in Buenos Aires have taken possession of small vacant areas in the city centre, such as government buildings, buildings abandoned by their owners, factories and warehouses, which they use as living quarters. These structures often lack adequate sanitation and electricity, and utilities such as water and power are often suspended due to lack of payment.

Despite the benefits of living in the city, the occupants of these structures live in squalid conditions, given their uncertain livelihoods and the poor quality of their housing (Herzer and Di Virgilio, 1996; Rodríguez and Di Virgilio, 2006).

To this must be added the withdrawal by the State of several public services which had, until the 1990s, guaranteed certain minimum living standards. Today, these services are very limited. In the 1990s,

\footnotetext{
${ }^{16}$ Increased overcrowding is one of the manifestations of poverty in formal settlements.

${ }^{17}$ The increase in the density of shantytowns recorded between the late 1990s and 2005 may have contributed to this shift; rather than leave the city, impoverished families chose to live in segregated urban areas.
} 
within the framework of government reforms, the internal logic underlying the reproduction of urban life underwent significant changes. Massive privatization of services pushed the management of collective urban consumption into the sphere of the market, leading to the mercantilization of basic urban services. This new model transfers the costs of living in the city directly to a worker's wages (Catenazzi and Di Virgilio, 2006). Access to services is determined almost entirely on the basis of a household's ability to muster the income necessary to cover a basic basket of goods and services.

Faced with this environment, households were forced to cut back on consumption of infrastructure services: water, gas, electricity, telecommunications and transportation. The declining purchasing power of the strata with the lowest incomes forced them to cut back on food and health care; they now had even less money available to improve their dwellings, pay their mortgages or cover service costs.

The limitations of the State were also reflected by the growing failure of urban public institutions — schools, hospitals, welfare offices - to address the needs of the poor. This is attributable to a lack of personnel and inputs, as well as the elimination of certain services, among other factors. The new poor interviewed for this article spoke of visiting hospitals where doctors still operate, but no beds, bandages or medicines are to be found; calling emergency rooms that still exist, but have no ambulances; sending their children to schools that are still open, but fail to teach certain subjects, remain inactive for months, or are staffed by teachers who take no interest in their job; saving money to buy sophisticated alarms that ring at the police station when the house is robbed, only to find that the police never come; and going to government offices that are where they have always been, but seem to have lost almost all their employees.

The enormity of impoverishment and the experiences it causes should not obscure the fact that another sector of the middle class "broke even" - that is, its circumstances did not vary significantly - and a minority moved upward during the 1990s. Nothing illustrates this phenomenon more clearly than the rise of inequality in the distribution of income throughout the decade; in the early 1990s, the average per capita income of the richest $10 \%$ of households was approximately 20 times that of the poorest $10 \%$. By the end of the decade, the ratio was 30 to one (Altimir and Beccaria, 1999). The "winners" of this process included sectors of the middle class that were closer to more dynamic areas of the economy. Svampa (2002 and 2004) has studied this sector, beginning with its exodus to the suburbs in the 1990s, when it moved to the more than 400 new gated communities and country clubs that sprang up around Buenos Aires and other big cities during this period. The first signs of suburbanization had already appeared years before, in Latin American cities such as Sao Paulo, Mexico, D.F. and Caracas, where it reached its fullest expression during the 1990s. The phenomenon has since spread to other cities, such as Santiago and Buenos Aires.

In order to achieve a general understanding of impoverishment, the evolution of other segments of the middle class must be studied as well. Thus, it should be noted that suburbanization is altering the entire landscape of urban Argentina. The idea of an "open city" (a primarily European concept), founded upon the notion of public space and values such as political citizenship and social integration, has been pushed aside in favour of the "closed city" model favoured by the United States. This model reaffirms private citizenship and reinforces social fragmentation. For many years, the "open city" model was followed in Argentina, despite its imperfections, within a social framework that explicitly recognized the value of a democratic society. During the 1990s, however, with the advent of suburbanization, the "winners" of the middle classes began to cut ties with their less fortunate neighbours, and move to areas formerly reserved for the upper classes. This process will, without question, lead to the final dilution of whatever cultural homogeneity the traditional middle class still possessed. Inside these closed communities, the winners have in effect begun to bond with the members of what has traditionally been known as the upper class. As noted by Svampa (2002 and 2004), despite differences in capital (particularly the economic and social kind) and class traditions, the upper classes and the successful sector of the middle classes now share similar consumption patterns, architectural tastes and, in some cases, work environments. In other words, they now share a common cultural and social framework that reflects the web of relationships underlying new forms of social interaction. 


\section{$\mathrm{V}$}

\section{Conclusions: the new poverty today}

After this overview, one might ask what changes have occurred among the new poor, if early research is compared to more recent studies. First, it should be noted that new poverty is no longer a novel phenomenon in Argentina. The great wave of impoverishment that swept the country in 2001 was harsher than the previous crisis, and its victims were more aware of what was happening to them. Many have been suffering the effects of pauperization for over a decade; this has caused social problems, such as a rise in foreclosures in large cities due to long-term delinquency. Second, many of the instances of downward mobility witnessed in the early 1990s appear to have been episodes in unstable trajectories. A study of occupational mobility in Argentina (Kessler and Espinoza, 2007) shows that some of those who became impoverished in the early 1990s saw their situation improve during later periods of growth, only to deteriorate afterwards. The trajectories and experiences of these individuals are not comparable to a fall with no partial recovery. The 1990s also witnessed structural upward mobility, that is, an increase, in both absolute and relative terms, in the number of jobs associated with the middle class because of the skills they require (Torrado, 1994). The benefits and well-being offered by these jobs declined, however, due to falling income and a general increase in job precarity. Consequently, many individuals experienced upward inter- or intra-generational mobility in terms of the skill classification of their jobs, but their wellbeing remained unchanged, or even declined. This phenomenon has been described as "spurious mobility" (Kessler and Espinoza, 2007).

Thirdly, the new poverty of the early 1990s was a "domestic" matter which did not generate group actions or strategies. By 2000, as shown by González Bombal (2002) in her study on the Barter Club - a system for the exchange of goods and services that grew to include two million people in 2001 - the middle class had come out into the open and devised collective strategies. Barter clubs provided a unique vantage point from which to observe the interaction between the impoverished middle classes and the lower classes. The latter obtained services (traditional and alternative healing, physical therapy) usually associated with the urban middle class, in exchange for goods (homecooked meals, and so on) and services (housekeeping, maintenance) associated with the lower class. These exchanges were interpreted differently by each class. For the lower classes, access to middle-class sectors and practices represented something of an upward move; for the new poor, they were yet another sign of the expulsion they so feared (Luzzi, 2005). One instance of massive departure from the middle class which included the new poor was the creation of neighbourhood assemblies in Buenos Aires, parts of the surrounding metropolitan area and cities in the interior, following the crisis of 2001. According to Svampa (2005), these organizational and deliberative bodies represented a departure from traditional forms of political representation, in favour of other forms of self-organization with horizontal aspirations and a propensity for direct action. These new experiences made the middle class an important political player, particularly in Buenos Aires, albeit for a short period of time.

The study of the novel phenomena that took place among the middle classes during the 1990s should not preclude a brief look at traditional or structural poverty. Those who studied poverty during the 1990s (including the authors of this article) deserve a measure of criticism in this regard. They were so captivated by what was happening among the country's middle socio-professional categories that they neglected to examine the impact of impoverishment on the entire social structure. As the middle classes became impoverished and vacated their positions due to rising unemployment, the traditional poor were pushed into low-skill jobs. Other jobs were reclassified as a result of the modernization process, and became closed to poor people with low educational attainment. In this competitive environment, the traditional poor became ineligible for certain positions, and the jobs they had traditionally occupied shifted to the middle classes, which were impoverished but possessed more skills. Porcú (2003) has examined the effects of the impoverishment of the middle class on the poorest members of the population (unemployment among domestic servants, for example). The strategies employed by the poor in the past, such as supplementing the head of household's income with his partner's job as a domestic servant, or relying entirely on the latter during unemployment crises, were also compromised by the impoverishment of the middle class. 
One final, resounding conclusion that may be drawn from this study is that the new poverty poses significant questions for public policy in different countries. These are questions which — at least in Argentina, which has been facing impoverishment for over a decade - have not been met with innovative policies. Such policies would have to include territorial components, since cities, and access to them, have been strongly affected by impoverishment. There can be no doubt that, in this new environment, tremendous creativity will be required; traditional approaches, such as those which focus on geographic areas inhabited by large numbers of poor people, are ineffective when dealing with a population scattered throughout cities. For those who have been following the phenomenon for years, including the authors of this article, it is disconcerting to find that, even though the issue is on the national agenda and occupies a place in the public mind, no policies have been developed for this population. While the existence and growth of "hard" poverty (which public policy has also failed to properly address) is certainly an issue, research by the authors a decade ago had shown that the remarkable impoverishment of the country's households was largely due to a lack of preventive policies. While this may not have been the initial cause of impoverishment, there can be no question that a number of measures —none of them particularly costly — would have helped impoverished households cushion the impact of the crisis and, above all, avoid the accumulation of needs that later came to a head.

Over the course of their research during the 1990s, the authors observed a lack of programmes to help cover rent and expenses, which might have averted evictions and foreclosures; a lack of resources to pay debts, which were manageable at first, and later became unpayable; the difficulty of paying medical bills, which forced patients to suspend treatment, causing permanent physical damage and even death; and families that took their young children out of school - supposedly on a temporary basis, to help support the household - and never re-enrolled them, creating a human capital deficit that later became irreversible. This was accompanied by the gradual deterioration of long-standing relationships, due to the "consumption" of social capital, which evaporated in the absence of reciprocity. Thus, at the precise moment they needed them the most, impoverished households fell further and further out of touch with their groups of belonging. As mentioned in the introduction to this article, the Argentine experience may be viewed as a model of similar processes elsewhere in the region. The mistakes made in Argentina — by action or by omission - should serve as a warning to other countries, to avoid suffering for vast sectors of the population.

(Original: Spanish)

\section{Bibliography}

Accardo, Alain and Philippe Corcuff (1986): La sociologie de Bourdieu, Bordeaux, Le Mascaret.

Altimir, Oscar and Luis Beccaria (1999): Distribución del ingreso en la Argentina, Reformas económicas series, No. 40, LC/L.1276-P, Santiago, Chile, Economic Commission for Latin America and the Caribbean (ECLAC).

Attewell, Paul, David Lavin and others (2004): The black middle class: progress, prospects, and puzzles, Journal of African American Studies, vol. 8, No. 1-2, New York, Springer.

Auletta, Ken (1982): The Underclass, New York, Random House.

Badcock, Blair (1984): Unfairly Structured Cities, Oxford, Blackwell.

Balsen, Werner, Hans Nakielski and others (1984): Die Neue Armut, Cologne, Bund Verlag.

Barthe, Marie-Anne (1987): Les formes de la pauvreté dans la société française, Revue française des affaires sociales, No. 2, Paris, Ministry of Social Affairs.

Bayón, Cristina (2006): Social precarity in Mexico and Argentina: Trends, manifestations and national trajectories, CEPAL Review, No. 88, LC/G.2289-P, Santiago, Chile, April.

Beccaria, Luis and Roxana Mauricio (2005): Inestabilidad laboral en el Gran Buenos Aires, Trimestre económico, vol. 71, No. 283, Mexico City, Fondo de Cultura Económica.
Blackburn, McKinley and David Bloom (1985): What is happening to the middle class?, American Demographics, vol. 7, No. 1, New York, Crain Communications, January.

Bolt, Gideon and Ronald van Kempen (2003): Escaping poverty neighbourhoods in the Netherlands, Housing, Theory and Society; vol. 20, No. 4, London, Routledge.

Bourdieu, Pierre (1979): Les trois états du capital culturel, Actes de la recherche en sciences sociales, No. 30, Paris, Centre de sociologie européenne du Collège de France.

Bucheli, Marisa and Magdalena Furtado (2004): Uruguay 19982002: características de los cambios en el perfil de la distribución del ingreso, Estudios y perspectivas series, No. 1, LC/L.2162-P, Montevideo, ECLAC office in Montevideo. United Nations publication, Sales No. S.04.II.G.90.

Caldeira, Teresa (1996): Fortified enclaves: the new urban segregation, Public Culture, vol. 8, No. 2, Durham, Duke University Press.

Carbonaro, Antonio (1979): Povertà e classi sociali. Per la critica delle ideologie sui processi di pauperizzazione, Milan, FrancoAngeli.

Castel, Robert (1995): Les métamorphoses de la quesion sociale. Une chronique du salariat, Paris, Fayard. 
Catenazzi, Andrea and María Mercedes Di Virgilio (2006): Habitar la ciudad: aportes para el diseño de instrumentos y la definición de una política urbana, in L. Andrenacci (ed.), Problemas de política social ( $Y$ la política social en problemas), Los Polvorines, Universidad Nacional de General Sarmiento.

Cefai, Daniel (1994): Type, typicalité, typification. La perspective phénoménologique, in Bernard Fradin, Louis Queré and Jean Widmer (eds.), L'enquete sur les catégories, Paris, École des Hautes Études en Sciences Sociales.

CELS (Centro de Estudios Legales y Sociales) (2001): La protesta social en la Argentina durante diciembre de 2001, Buenos Aires.

Comunidad Económica Europea (1988): Social Europe, Brussels.

Cortés, Fernando and Agustín Escobar Latapí (2005): Intergenerational social movility in urban Mexico, CEPAL Review, No. 85, LC/G.2266-P, Santiago, Chile, Economic Commission for Latin America and the Caribbean (ECLAC), April.

Cortés, Rosalía and Gabriel Kessler (2003): Intervenciones sociales y acción comunitaria. Informe sobre situación de población empobrecida de la comunidad judía, New York, American Joint Distribution Committee.

(2004): Informe sobre la situación de beneficiarios de planes asistenciales de instituciones comunitarias, unpublished.

De Regt, Alí and Don Weenink (2000): Angs voor sociale daling? De functies van particulier onderwijs, Amsterdams Sociologisch Tijdschrift, vol. 27, No. 3, Amsterdam, Stichting Amsterdams Sociologisch Tijdschrift.

Del Cueto, Carla (2007): Los únicos privilegiados, Buenos Aires, Universidad Nacional de General Sarmiento (UNGS)/ Prometeo.

Devine, Joel and James Wright (1993): The Greatest of Evils: Urban Poverty and the American Underclass, New York, Aldine.

Di Virgilio, María Mercedes (2003): Hábitat y salud. Estrategias de las familias pobres, Buenos Aires, Ediciones Lumiere.

Elder, Glen (1974): Children of the Great Depression: Social Change in Life Experiences, Chicago, University of Chicago Press.

Espinoza, Vicente (2006): La movilidad ocupacional en el Cono Sur. Oportunidades y desigualdad social, Revista de sociología, No. 20, Santiago, Chile, Faculty of Social Sciences, University of Chile.

Feijoó, María del Carmen, (1992): Los gasoleros: estrategia de consumo de los NUPO, in Alberto Minujin (ed.), Cuesta abajo. Los nuevos pobres: efectos de la crisis en la sociedad argentina, Buenos Aires, UNICEF-Losada.

(2001): Nuevo país, nueva pobreza, Buenos Aires, Fondo de Cultura Económica.

Fothergill, Alice (2003), The stigma of charity: gender, class and disaster assistance, The Sociological Quarterly, vol. 44, No. 4, Oxford, United Kingdom, Blackwell Publishing.

Gaffikin, Frank and Mike Morrisey (1992): The New Unemployed. Joblessness and Poverty in the Market Economy, London, Zed Books.

Germani, Gino (1963), Movilidad social en la Argentina, in Seymour Lipset and Reinhardt Bendix (eds.), Movilidad social en la sociedad industrial, Buenos Aires, Eudeba.

González Bombal, Inés (2002): Sociabilidad en clases medias en descenso: experiencias en el trueque, Sociedad y sociabilidad en la Argentina de los 90, Buenos Aires, Universidad Nacional de General Sarmientos (UNGS)/Biblos.
Grupo CCR (2005): Marcas masivas, mercados fragmentados, Buenos Aires, Instituto Argentino de la Empresa.

Herzer, Hilda and María Mercedes Di Virgilio (1996): Buenos Aires: pobreza e inundación, in Hilda María Herzer and María Mercedes Di Virgilio, EURE: Revista Latinoamericana de Estudios Urbano Regionales, Santiago, Chile, Institute for Urban Studies, Catholic University of Chile.

Hirschman, Albert (1970): Exit, Voice and Loyalty, Cambridge, Massachusetts, Harvard University Press.

Hoffman, Kelly and Miguel Angel Centeno (2003): The lopsided continent: inequality in Latin America, Annual Review of Sociology, vol. 29, Palo Alto, California, Annual Reviews.

Ilkhamov, Alisher (2001): The impoverishment of masses in the transition period: signs of an emerging 'new poor' identity in Uzbekistan, Central Asian Survey, vol. 20, No. 1, London, Routledge.

INDEC (National Institute of Statistics and Censuses) (2003): http:// www.indec.gov.ar

Kazemipur, Abdolmohammed and Shiva Halli (2001), Immigrants and 'new poverty': the case of Canada, The International Migration Review; vol. 35, No. 4, New York, Center for Migration Studies of New York, Inc.

Kaztman, Rubén (1989): La heterogeneidad de la pobreza en Montevideo: una aproximación bidimensional, La economía de América Latina, No. 18, Montevideo, Facultad de Ciencias Económicas y de Administración, Universidad de La República.

Kaztman, Rubén, Fernando Filgueira and others (2005): La ciudad fragmentada. Respuesta de los sectores populares urbanos a las transformaciones del mercado y del territorio en Montevideo, in Alejandro Portes, Bryan Roberts and Alejandro Grimson (ed.), Ciudades latinoamericanas. Un análisis comparativo en el umbral del nuevo siglo, Buenos Aires, Prometeo.

Kelly, Mark (1984): The Poor Aren't News, Dublin, Simon Community.

Kessler, Gabriel (1998): Le processus de paupérisation de la classe moyenne argentine, thesis, Paris, Ecole des Hautes Etudes en Sciences Sociales.

(2000): Redefinición del mundo social en tiempos de crisis. Sobre el uso del capital social en clases medias empobrecidas, in M. Svampa (ed.), Desde abajo, Buenos Aires, Biblos/ Universidad Nacional de General Sarmiento (UNGS).

(2008), Infancias vulnerables, Buenos Aires, American Joint.

Kessler, Gabriel and Vicente Espinoza (2007): Movilidad social y trayectorias ocupacionales en Buenos Aires. Continuidades, rupturas y paradojas, in Rolando Franco, Arturo Léon and Raul Atria (coords.), Estratificación social en América Latina. Transformaciones estructurales de un cuarto de siglo, Santiago, Chile, ECLAC-LOM.

Kessler, Gabriel and Mercedes Di Virgilio (2005): The new poverty in Argentina and Latin America, in Lisa Hanley, Blair Ruble and Joseph Tulchin (eds.), Becoming Global and the New Poverty of Cities, Washington, D.C., Woodrow Wilson International Center for Scholar/United States Agency for International Development (USAID).

Kryshtanovkaia, Ol'ga (2005): Has-Beens: trends of downward mobility of the Russian elite, Sociological Research, vol. 44, No. 2, Armonk, M.E. Sharpe. 
Ladanyi, Janos e Ivan Szelenyi (2002): Ciganyok es szegeneyek Magyararoszagon, Romaniaban es Bulgarian, Szociological Szemle, No. 4.

Lomnitz, Larissa (1975): ¿Cómo sobreviven los marginados?, Mexico City, Siglo XXI.

Lomnitz, Larissa and Ana Melnick (1991): Chile's Middle Class. A Struggle for Survival in the Face of Neoliberalism, Boulder, Colorado, Latin American and Caribbean Centre.

López, Julio (1999): Evolución reciente del empleo en México, Reformas económicas series, No. 29, LC/L.1218-P, Santiago, Chile, Economic Commission for Latin America and the Caribbean (ECLAC), July.

Luzzi, Mariana (2005): Reinventer le marché? Les clubs de troc face à la crise en Argentina, Paris, L'Harmattan.

Marklund, Staffan (1990): Structures of modern poverty, Acta sociologica, vol. 33, No. 2, Thousand Oaks, Sage Publications.

McDowell, Linda (2002): Transitions to work: masculine identities, youth inequality and labour market change, Gender, Place and Culture, vol. 9, No. 1, London, Routledge.

McMahon, Patrick and John Tschetter (1986): The declining middle class: a further analysis, Monthly Labor Review, vol. 109, No. 9, Washington, D.C., Bureau of Labor Statistics.

Mead, Laurence (1986): Beyond Entitlements, New York, The Free Press.

Mingione, Enrico and Francesa Zajczyk (1992): Le nuove povertà urbane in Italia: modelli di percorsi a rischio nell'area metropolitana milanese, Inchiesta, No. 97-98, Bari, Dedalo.

Minujin, Alberto (ed.) (1992): Cuesta abajo. Los nuevos pobres: efectos de la crisis en la sociedad argentina, Buenos Aires, UNICEF-Losada.

Minujin, Alberto and Gabriel Kessler (1995): La nueva pobreza en la Argentina, Buenos Aires, Temas de Hoy/Planeta.

Mitev, Petar-Emil (2001): A szegenyseg dinamikaja [Dynamics of Poverty], Szociologiai Szemle, No. 4.

Molina, Irene (2001): Segregación habitacional étnica en la ciudad sueca. Un proceso de racialización, Scripta nova. Revista electrónica de geografía y ciencias sociales, No. 90, Barcelona, University of Barcelona

Montero, Sary and Manuel Barahona (2003): La estrategia de lucha contra la pobreza en Costa Rica. Institucionalidad - Financiamiento - Políticas - Programas, Polítias sociales series, No. 77, LC/L.2009-P, Santiago, Chile, Economic Commission for Latin America and the Caribbean (ECLAC). United Nations publication, Sales No. S.02.II.G.170.

Mora y Araujo Manuel (2007): Evidencia y conjeturas acerca de la estratificación actual en Argentina, in Rolando Franco, Arturo Léon and Raul Atria (coords.), Estratificación social en América Latina. Transformaciones estructurales de un cuarto de siglo, Santiago, Chile, ECLAC-LOM.

Mota Guedes, Patricia and Nilson Vierra Oliveira (2006): La democratización del consumo, Braudel Papers, No. 19, São Paulo, Instituto Fernand Braudel de Economía Mundial.

Murray, Charles (1984): Losing Ground, New York, Basic Books.

Neef, R. (1992): The new poverty and local government social policies: a West German perspective, International Journal of Urban and Regional Research, vol. 16, No. 22, Oxford, United Kingdom, Blackwell Publishing.
Newman, Katherine (1989): Falling from Grace. The Experience of Downward Mobility in the American Middle Class, New York, Vintage Books.

(1993): Declining Fortunes. The Withering of the American Dream, New York, Basic Books.

O'Higgins, Mark and Stephan Jenkins (1989): Poverty in Europe: estimates for the numbers in poverty in 1975, 1980, 1985, Bath, University of Bath.

O'Dougherty, Maureen (1999): The devalued state and nation: neoliberalism and the moral economy discourse of the Brazilian middle class, 1986-1994, Latin American Perspectives, vol. 26, No. 104, Thousand Oaks, Sage Publications.

Parrado, Emilio (2005): Economic restructuring and intragenerational class mobility in Mexico, Social Forces, vol. 84, No. 2, Chapel Hill, University of North Carolina.

Paugam, Serge (1991): La disqualification sociale. Essai sur la nouvelle pauvreté, Paris, PUF.

(1993): La société française et ses pauvres. L'expérience de revenu minimum d'insertion, Paris, PUF.

Porcú, Patricia (2003): Proceso de movilidad descendente de los noventa. El impacto de la pérdida del trabajo en los hogares pobres, Buenos Aires, FLACSO Argentina.

Portes, Alejandro and Min Zhou (1993): The new second generation: segmented assimilation and its variants among post-1965 immigrant youth, Annals of the American Academy of Political and Social Science, vol. 530, Thousand Oaks, Sage Publications.

Prevot Schapira, Marie-France (2002): Buenos Aires en los 90, metropolización y desigualdades, EURE: Revista de Estudios Urbano Regionales, vol. 28, No. 85, Santiago, Chile, Catholic University of Chile. Available in http://redalyc.uaemex. $\mathrm{mx} /$ redalyc/src/inicio/ArtPdfRed.jsp?iCve $=19608503 \&$ iCve Num=503

Rodríguez, María Carla and María Mercedes Di Virgilio (2006): Políticas de tierra y vivienda y déficit habitacional en el Área Metropolitana de Buenos Aires, Revista argentina de sociología, Buenos Aires, Consejo de Profesionales en Sociología, forthcoming.

Room, Graham (1989): 'New Poverty' in the European Community, London, MacMillan.

Rosenthal, Neal (1985): The shrinking middle class: myth or reality?, Monthly Labor Review, vol. 108, No. 3. Washington, D.C., Bureau of Labor Statistics.

Sabatini, Francisco and Guillermo Wormald (2005): Crecimiento, modernización y oportunidades de integración social, en Alejandro Portes, Bryan Roberts and Alejandro Grimson (eds.), Ciudades latinoamericanas. Un análisis comparativo en el umbral del nuevo siglo, Buenos Aires, Prometeo.

Sabogal, Elena (2005): Viviendo en la sombra: the immigration of Peruvian professionals to South Florida, Latino Studies, vol. 3, No. 1, Houndmills, Palgrave Macmillan.

Schutz, Alfred (1987): Le chercheur et le quotidien, Paris, Méridiens Klincksieck.

SIEMPRO (2001): Encuesta de Condiciones de Vida (ECV). Base usuario, Buenos Aires, Ministry of Social Development.

Sigal, Silvia and Gabriel Kessler (1997): Comportements et représentations dans une conjoncture de dislocation des 
régulations sociales. L'hyperinflation en Argentine, Culture \& conflits, No. 24-25, Paris, Centre d'Etudes sur les Conflits.

So, Alvin (2004): The middle class in Asia-Pacific: second phase and future trajectory, Asian Perspective, vol. 28, No. 2, Seoul, Institute for Eastern Studies.

Søholt, Susanne (2001): Ethnic minority groups and strategies in the housing market in Oslo. European Journal of Housing Policy, vol. 1, No. 3, London, Routledge.

Strobel, Frederick (1993): Upward Dreams, Downward Mobility. The Economic Decline of the American Middle Class, Lanham, Maryland, Rowman\&Littlefield Publishers Inc.

Svampa, Maristella (2002): Los que ganaron. La vida en los countries y barrios privados, Buenos Aires, Biblos.

(2004): La brecha urbana. Countries y barrios privados en Argentina, Buenos Aires, Colección Claves para Todos-Le Monde Diplomatique.

(2005): La sociedad excluyente. La Argentina bajo el signo del neoliberalismo, Buenos Aires, Taurus.

Tironi, Manuel (2003): Nueva pobreza urbana. Vivienda y capital social en Santiago de Chile, 1985-2001, Santiago, Chile, University of Chile/ PREDES/ Ril Editores.

Titma, Mikk and Rein Murakas (2004): Income inequalities in the Baltic states, International Journal of Sociology, vol. 34, No. 2, Armonk, M.E. Sharpe.

Torche, Florencia (2005): Unequal but fluid: social mobility in Chile in comparative perspective, American Sociological Review, vol. 70, No. 3, Washington, D.C., American Sociological Association.

Torche, Florencia and Guillermo Wormald (2004): Estratificación y movilidad social en Chile: entre la adscripción y el logro, Políticas sociales series, No. 98, LC/L.2209-P, Santiago, Chile,
Economic Commission for Latin America and the Caribbean (ECLAC). United Nations publication, Sales No. S.04.II.G.32.

Torrado, Susana (1994): Estructura social de la Argentina: $1945-$ 1983, Buenos Aires, Ediciones La Flor.

Tortosa, José (1992): La pobreza capitalista, Madrid, Tecnos.

Ugalde, Pamela and José Joaquín Prieto (2001): Caracterización de la clase media en Chile durante los noventa, informe preliminar, Santiago, Chile, Faculty of Social Sciences, University of Chile.

Valladares, Licia, Edmond Préteceille and others (2005): Río de Janeiro en el viraje hacia el nuevo siglo, in Alejandro Portes, Bryan Roberts and Alejandro Grimson (eds.), Ciudades latinoamericanas. Un análisis comparativo en el umbral del nuevo siglo, Buenos Aires, Prometeo.

Vega Martínez, Mylena (1999): La clase media en transición: situación y perspectivas al finalizar el siglo veinte, Revista de ciencias sociales, No. 86-87, San José, University of Costa Rica.

Waldinger, Roger and Cynthia Feliciano (2004): Will the new second generation experience 'downward assimilation'? Segmented assimilation re-assessed, Ethnic and Racial Studies, vol. 27, No. 3, London, Taylor \& Francis.

Wilson, Julius (1987): The Truly Disadvantaged: the Inner City, the Underclass and Public Policy, Chicago, University of Chicago Press.

Wormald, G., L. Cereceda and P. Ugalde (2002): Estructura de oportunidades y vulnerabilidad social: los grupos pobres en la Región Metropolitana de Santiago de Chile en los años 90, in R. Katzman and G. Wormald (coords.), Trabajo y ciudadanía. Los cambiantes rostros de la integración y exclusión social en cuatro áreas metropolitanas de América Latina, Montevideo, Cebra. 